Linha D'Água (Online), São Paulo, v. 33, n. 3, p. 25-54, set.-dez. 2020

\title{
CRÍTICA RESPONSIVA A DIÁLOGOS POLÊMICOS COM O CONCEITO DE DIALOGISMO DE BAKHTIN
}

\section{ANSWERABLE CRITIQUE OF CONTROVERSIAL DIALOGUES WITH BAKHTIN'S CONCEPT OF DIALOGISM}

\author{
Marco Antonio Villarta- $\mathcal{N}$ eder* \\ Universidade Federal de Lavras, Lavras, MG, Brasil \\ Fábio Luiz de Castro Dias** \\ Universidade Federal de Lavras, Lavras, MG, Brasil
}

\begin{abstract}
Resumo: Em discussões de grupo de pesquisa deparou-se com cíticas ao conceito bakhtiniano de dialogismo, questionando sua viabilidade epistemológica. Caryl Emerson endossa visões desse conceito como "demasiado frouxo e indisciplinado". Ignora que já em Arte e Responsabilidade, Bakhtin considera indissociáveis as dimensões da vida, da arte e da ciência. Em Problemas da Criação de Dostoiéuskie em Problemas da Poética de Dostoiévski, ele aponta que no mundo de Dostoiévski não há nada que tenha dito sua última palavra, que nõo suscite uma resposta. A partir disso, nosso objetivo é discutir o conceito de dialogismo a partir da produção bakhtiniana sobre Dostoiévski. A metodologia de análise, contrapontística e dialógica, baseia-se, principalmente, no correlacionamento de obras do Círculo de Bakhtin. Os resultados esperados apontam, de um lado, um viés de leitura do conceito de dialogismo com uma polêmica compreensão teórico-epistemológica-axiológica e, de outro, possíveis contextos de recepção desse conceito de maneira mais acurada.
\end{abstract}

Palavras-chave: Círculo de Bakhtin; diálogo; Problemas da criação de Dostoiéeskki; Problemas da poética de Dostoiévski; concepção dialético-dialógica da linguagem.

\begin{abstract}
In research group discussions we came across criticism of the Bakhtinian concept of Dialogism, questioning its epistemological feasibility. Caryl Emerson endorses views of this concept as "too loose and undisciplined". She ignores that in Art and Responsibility, Bakhtin considers inseparable the dimensions of life, art and science. In Dostoyevsky's Problems of Creation and Dostoyevsky's Problems of Poetics, Bakhtin points out that in Dostoyevsky's world there is nothing that has said his last word that does not elicit an answer. Based on that, our aim is to discuss the concept of dialogism from the Bakhtinian production in Dostoyevsky. The methodological analysis, dialectical and dialogic, is based on a correlation (coотнесение - sootnessenie) from the Bakhtin Circle works. The expected results point out, firstly, a bias in reading this concept with a controversial theoretical-epistemological-axiological understanding and, on the other hand, possible contexts of receiving this concept in a more accurate way.
\end{abstract}

\footnotetext{
* Professor doutor da Universidade Federal de Lavras - UFLA, Lavras, MG, Brasil; http://orcid.org/0000-0003-3857-3720; villarta.marco@ufla.br

* * Graduando em Letras pela Universidade Federal de Lavras - UFLA, Lavras, MG, Brasil; http://orcid.org/0000-0002-6755-1048; castrodias.f.l@gmail.com
}

http://dx.doi.org/10.11606/issn.2236-4242.v33i3p25-54 
Linha D’Água (Online), São Paulo, v. 33, n. 3, p. 25-54, set.-dez. 2020

Keywords: Bakhtin's Circle; dialogue; Problems of Dostoevsky's Creation; Problems of Dostoevsky's Poetics; dialectical-dialogical conception of language.

\section{Considerações iniciais ${ }^{1}$}

Quando da submissão de nosso trabalho para o Colóquio Internacional "90 anos de Problemas da Obra de Dostoiérski" (1929-2019), encontrávamo-nos à mercê de uma série de inquietações que remontam às nossas discussões realizadas em uma disciplina do Programa de Pós-Graduação em Letras da Universidade Federal de Lavras (UFLA), que se desenvolveram mais, na sequência, nas reuniões acadêmicas do nosso grupo de pesquisa GEDISC/UFLA/CNPq (Grupo de Estudos Discursivos sobre o Círculo de Bakhtin).

À época, ao nos dedicarmos especificamente às discussões analíticas sobre os conceitos de dialogismo e de polifonia do filósofo Mikhail Bakhtin [1895-1975], utilizamo-nos, como um contraponto e um complemento, do texto Os 100 primeiros anos de Mikhail Bakbtin (2003), de Caryl Emerson, em diálogo com o de Bulavka e Buzgalin, Os próximos 100 anos de Mikhail Bakbtin: a dialética do diálogo versus a metafísica do Pós-Modernismo (2005). Pela razão de o conceito de polifonia da perspectiva de Bakhtin encontrar-se desenvolvido, de modo mais detalhado, nas reflexões do filósofo sobre a produção do escritor russo Fiódor Dostoiévski [1821-1881], o nosso foco inicial se fixou no texto Problemas da poética de Dostoiérski (2013) - PPD daqui em diante -, cuja primeira edição, na Rússia (União Soviética à época da publicação de $P P D)$, data de $1961^{2}$.

A oportunidade de submissão de nosso trabalho ao evento baseado em Problemas da criação de Dostoiérski $i^{3}$ - PCD daqui em diante -, texto de 1929, que se

1 Foi adotado o critério geral de transliteração das palavras russas em alfabeto cirílico a convenção utilizada pelo jornal Folha de $S$. Paulo, com exceção do $b l$, que preferimos transliterar como " $y$ " para evitar confusões com a transliteração do и.

2 Na verdade, há dois textos de 1961, mas a primeira edição foi lançada em 1963. (SOUZA, 2002, Anexo, p. 19)

3 Na edição italiana, editada, organizada e traduzida por Augusto Ponzio (2014), o título da versão de 1929 encontra-se como Problemi dell'opera di Dostoevskij (em português, Problemas da obra de Dostoiévski). Em russo, encontra-se, por sua vez, como Проблемы творчества

VILLARTA-NEDER, M. A., DIAS, F. L. C. Crítica responsiva a diálogos polêmicos com 0 conceito de dialogismo de Bakhtin 
Linha D’Água (Online), São Paulo, v. 33, n. 3, p. 25-54, set.-dez. 2020

tornou, com certas modificações de Bakhtin, o embrião a partir do qual se formou $P P D$, levou-nos a um recorte analítico dentro do qual se focalizam dados aspectos conceituais de ambas as obras de Bakhtin. Consequentemente, as nossas discussões nos direcionaram à percepção segundo a qual se formam os contrapontos críticos de Emerson, os quais se subsidiam em contribuições de críticos russos, europeus e norte-americanos. Tais contribuições são consideradas plausíveis com relação à construção epistemológica e lógica do conceito de polifonia de Bakhtin, o mesmo, no entanto, não ocorre no que se refere ao de dialogismo.

Fundamentada sobre a desconsideração de uma parte importante da organização conceitual e lógica do campo epistemológico da filosofia bakhtiniana, como assim nos parece, uma crítica à conceituação de dialogismo de Bakhtin constituiu-se como o centro de nossas atenções, tornando-se um desconforto de leitura reforçado pelos engajamentos de outros autores - como o de Bulavka e Buzgalin -, que confrontavam as posições críticas endossadas por Emerson. Segundo o nosso entendimento, trata-se não somente de imprecisões teórico-epistemológicas em relação à configuração e à organização da rede epistêmica e lógica do campo do Círculo de Bakhtin, mas, sobretudo, de um posicionamento axiológico em embate com a perspectiva da responsabilidade ética pelo não-álibi, pilar da construção geral das análises e das teorizações do Círculo. Daí, derivou-se, então, um outro motivo relevante para o estabelecimento de um segundo nível de recorte em nossas análises, que passou a incidir sobre o conceito de dialogismo.

Dentre os muitos críticos sobre os quais Emerson se apoia, destacam-se Mikhail Gasparov [1937-2005] e Aaron Fogel [1947-]. A crítica do primeiro tenta justificar-se sobre a premissa segundo a qual o conceito de dialogismo se revela como "[...] demasiado frouxo e indisciplinado em face do objeto de estudo" (GASPAROV, 1993 apud EMERSON, 2003, p. 198-199). Em mesma direção, a confrontação do crítico russo, de tom denunciativo, incide sobre a observação da

Достоевского (Probliêmy tvórtchestva Dostoiévskogo) (2014). O vocábulo mворчества (tvórtchestva), contudo, traduz-se melhor como criação em vez de obra, dado o aspecto processual da ideia de Bakhtin sobre a atividade estética de Dostoiévski. Trata-se da mesma palavra usada no título de Estética da criação verbal (201 1), de Trad. de Paulo Bezerra - Эстетика словесного творчества (Estetika sloviêsnova tvórtchestva) (1986). Vamos nos utilizar, portanto, do título Problemas da criação de Dostoiévski.

VILLARTA-NEDER, M. A., DIAS, F. L. C. Crítica responsiva a diálogos polêmicos com 0 conceito de dialogismo de Bakhtin 
persistência de uma necessidade de evocar, em uma ampla gama de disciplinas, o desejo de que as coisas "falem comigo, em meus próprios termos" (GASPAROV, 1993 apud EMERSON, 2003, p. 198-199). Por sua vez, o segundo funda-se sobre uma confusão epistemológica a respeito do referido conceito de Bakhtin. O diálogo, segundo o seu entendimento, não corresponderia à realidade das relações humanas. Para Fogel, o dialogismo, logo, não pode se configurar como uma categoria conceitual de validade epistêmica.

O texto de Emerson, então, constrói-se a partir de um delineamento de certas faces escolhidas e recortadas das posições de Bakhtin à luz, sobretudo, de detratores da epistemologia bakhtiniana. Pela lógica da sua argumentação, o leitor pode ser levado à crença de que a escrituração se constitui como um gênero aporético. Ao seu interlocutor, parece-nos se deixar o julgamento final (crítico) das posições elencadas pela sua atividade descritiva segundo os seus encadeamentos retóricos. Não se trata, porém, do que se efetiva. $\mathrm{O}$ tom das discussões e o balanceamento dos argumentos parecem indicar uma outra vontade discursiva ${ }^{4}$ da autora.

Emerson, conhecedora de Fragmentos de 1970-19715 (2017a) de Bakhtin, não se dedica à percepção, ao elencar os argumentos dos críticos que questionam o conceito bakhtiniano de dialogismo, do caráter problemático das configurações pelas quais se forma o seu posicionamento, esquecendo-se do trecho no qual se afirma, de maneira explícita, a compreensão de Bakhtin sobre a natureza da sua concepção de diálogo a partir dos limites entre as palavras de um eu e de um outro como uma "[...] tensa luta dialógica" (BAKHTIN, 2017a, p. 38).

Deixa-se desconsiderar, de igual maneira, o posicionamento de Bakhtin em Arte e responsabilidade (2011b), no qual se mostram indissociáveis, enquanto tomada de posição - nocmynok (postúpok) - de um sujeito histórico, as dimensões da vida, da arte e da ciência, que se consubstanciam e se compreendem na unidade da sua responsabilidade sob a força do imperativo da alteridade. E, aí, forma-se uma confluência: tanto em Problemas da criação de Dostoiérski (de 1929), quanto em Problemas da poética de Dostoiéruski (de 1963), manifesta-se a consideração de

\footnotetext{
4 Uma das possíveis traduções adotadas para a expressão russa речвая воля (rietchváia vólia).

5 Traduziu-se como, também, Apontamentos de 1970-1971 na edição brasileira (BAKHTIN, 2011 a) de Estética da criação verbal de Trad. de Paulo Bezerra. Trata-se de um texto de 1979.
}

VILLARTA-NEDER, M. A., DIAS, F. L. C. Crítica responsiva a diálogos polêmicos com 0 conceito de dialogismo de Bakhtin 
Linha D’Água (Online), São Paulo, v. 33, n. 3, p. 25-54, set.-dez. 2020

Bakhtin segundo a qual não se constrói, no universo do romance dostoievskiano, a última palavra. Em Dostoiévski, o mundo dos personagens se configura como, de modo necessário, uma atitude responsiva sob a égide de uma alteridade absoluta de forma constitutiva, profunda, conflituosa, tensa e reguladora. Há, logo, sempre uma suscitação contínua de uma série de respostas conflitivas, percepção presente nas reflexões do Círculo de Bakhtin de maneira geral.

Eis as questões através das quais nos levamos à definição de nosso objetivo: a discussão do tenso diálogo de críticos com os enunciados do Círculo de Bakhtin sobre, estritamente, o conceito de dialogismo a partir da produção sobre Dostoiévski, mas em apreço, também, das demais obras bakhtinianas. A nossa metodologia de análise, contrapontística e dialógica, realiza-se por meio do princípio do correlacionamento ${ }^{6}$ de Bakhtin (BAKHTIN, 2017b, p. 66-67). Os resultados esperados nos direcionam para, de um lado, um viés de leitura do conceito de dialogismo sem a necessária compreensão epistemológica e axiológica e, de um outro, de possíveis contextos de recepção responsiva do conceito bakhtiniano de maneira mais acurada.

\section{Metodologia}

Em coerência com a teoria bakhtiniana, o nosso artigo organiza-se sob o princípio metodológico do correlacionamento (BAKHTIN, 2017b, p. 67), ao qual se liga a nossa atitude ética enquanto pesquisadores entranhados no caráter analítico e interpretativo da epistemologia do Círculo de Bakhtin. $\mathrm{O}$ correlacionamento define-se como o meio pelo qual se instaura, através da nossa compreensão ativa, a intersecção dialógica entre as obras das quais nos utilizamos como enunciados responsivos - высказывание (әyskázyvanie), por cujas responsividades retrospectivas e prospectivas se forma uma das séries de uma cadeia da comunicação discursiva (GRILLO; AMÉRICO, 2018, p. 357) - na qual nos inserimos, também.

Um enunciado, logo, caracteriza-se como mônada axiológica e semântica no interior da qual se funda uma contínua interação dialógica entre sujeitos históricos, a partir das condições ideológicas e materiais da sociedade na qual se encontram.

6 Coотнесение (sootnessenie)

VILLARTA-NEDER, M. A., DIAS, F. L. C. Crítica responsiva a diálogos polêmicos com 0 conceito de dialogismo de Bakhtin 
Linha D’Água (Online), São Paulo, v. 33, n. 3, p. 25-54, set.-dez. 2020

Para além da sua estrutura e da sua forma, constituem-se os seus sentidos ideológicos aos quais se ligam - e por meio dos quais se organizam - os aspectos concretos dos seus contextos de produção, de circulação e de recepção (BRAIT; MELO, 2016). Para o enunciado, fazem-se necessárias, então, as presenças históricas dos sujeitos da comunicação dialógica (BAKHTIN, 2016, p. 29).

Fundando-se, então, sobre o nosso entendimento segundo o qual as obras das quais nos utilizamos se configuram como enunciados responsivos, a nossa atividade analítica delineia-se por meio de uma interpretação ativa, que se define, segundo Bakhtin (2017b, p. 66), como "[...] o correlacionamento de dado texto com outros textos", uma vez que:

um texto só tem vida contatando com outro texto (contexto). Só no ponto desse contato de textos eclode a luz que ilumina retrospectiva e prospectivamente, fazendo dado texto comungar no diálogo. Salientemos que esse contato é um contato dialógico entre textos (enunciados) e não um contato mecânico de "oposição" (BAKHTIN, 2017b, p. 67).

Daí, deriva o nosso uso do princípio do correlacionamento, por meio do qual se constrói um tenso diálogo entre as inúmeras vozes pelas quais se orienta a nossa escrituração. Em um primeiro momento, correlacionamos determinadas obras bakhtinianas na seção Referencial teórico, que se entrelaçam com, em um segundo, as demais vozes na seção Análise, na qual nos utilizamos de um procedimento arqueológico ao nos remetermos a aspectos pontuais da filosofia de determinados filósofos, dialogicamente.

Esperamos que transpareça ao leitor nossa visão e nossa utilização das obras de alguns integrantes do Círculo de Bakhtin como, em certo grau, a fundamentação teórica e o objeto analítico de nosso artigo, concomitantemente. Mas, de maneira restrita, as nossas análises epistemológicas da teoria bakhtiniana se formam como a base teórica sobre a qual se sustenta este trabalho e é por meio dela que se organizam, a propósito, as nossas interpretações analíticas de nosso objeto central: o texto de Emerson, no qual se mostram, por meio da argumentação da autora estadunidense, uma série de vozes enunciativas em polêmica crítica com a epistemologia bakhtiniana.

VILLARTA-NEDER, M. A., DIAS, F. L. C. Crítica responsiva a diálogos polêmicos com 0 conceito de dialogismo de Bakhtin 
Linha D’Água (Online), São Paulo, v. 33, n. 3, p. 25-54, set.-dez. 2020

\section{Referencial teórico}

O dialogismo, enquanto uma proposta filosófica e linguística de compreensão da condição humana e da produção cultural, encontra-se dispersa pelas obras de parte dos integrantes do Círculo de Bakhtin, como, de mesma maneira, no pensamento do linguista russo Lev Iakubinski ${ }^{7}$ [1892-1945] e do filósofo alemão Martin Buber $^{8}$ [1878-1965], por exemplo. Para além de uma marcação, explícita ou implícita, de uma multiplicidade de vozes em uma organização composicional de um enunciado, trata-se, para o Círculo de Bakhtin, de um entendimento metafórico da alteridade da qual se tornam dependentes as estruturas de formação do próprio sujeito, cujos modos se refratam na base de constituição e de configuração de quaisquer produções da cultura humana na história, sob diferentes formas.

Um dos mais clássicos exemplos se situa na compreensão de Bakhtin da obra de Dostoiévski em PPD, livro no qual nos demonstra, sobretudo, o dialogismo enquanto uma compreensão da alteridade constitutiva e reguladora do ser humano, como a fundação da composição narrativa das obras dostoievskianas que se refrata na organização psicológica e sociológica dos personagens do escritor russo, atrelando-se ao princípio da polifonia. De outro modo, manifestam-se os dois níveis do dialogismo em Dostoiévski: o arquitetônico e o composicional, que se entrelaçam de modo consubstancial e dependente. Sobral (2010, p. 67-68), de forma sintética, afirma que:

[...] o dialogismo se faz presente de três maneiras distintas: (1) como princípio geral do agir e mesmo do ser: só se age/se é em relação de contraste com respeito a outros atos de outros sujeitos/a outros sujeitos. Logo, o vir-a-ser do indivíduo e do sentido está fundado na diferença, no confronto eu-tu; (2) como princípio de produção de enunciados/discursos, que advém de "diálogos" retrospectivos e prospectivos com outros enunciados/discursos; e (3) como forma específica de composição de enunciados/discursos, opondo-se nesse caso à forma de composição monólogo, embora nenhum enunciado/discurso seja constitutivamente monológico nos dois outros sentidos.

7 Sobre a fala dialogal (2015).

8 Do diálogo e do dialógico (1982).

VILLARTA-NEDER, M. A., DIAS, F. L. C. Crítica responsiva a diálogos polêmicos com 0 conceito de dialogismo de Bakhtin 
Em PPD (2013), Bakhtin nos oferece a certeza segundo a qual o dialogismo se mostra como o preceito, em caráter absoluto, de compreensão da condição humana, pelo qual o sujeito se manifesta como um ser lançado à imanência do mundo histórico sob o imperativo ético da alteridade inelutável, não se limitando apenas a um princípio de escolha e de organização da composição estilística e formal da narrativa do escritor russo. As estruturas ontológicas dos personagens dostoievskianos, que se dão como arquétipos da condição humana em geral, marcamse como dialógicas. Desde a percepção de si à representação do mundo, o sujeito se caracteriza como atravessado pelo outro. Segundo as palavras de Bakhtin (2013, p. 293), "nos romances de Dostoiévski tudo se reduz ao diálogo, à contraposição dialógica como centro. Tudo é meio, o diálogo é o fim. Uma só voz nada termina e nada resolve. Duas vozes são o mínimo de vida, o mínimo de existência”. Ou seja, trata-se, de um modo geral, da "[...] contraposição do homem ao homem como contraposição do 'eu' ao 'outro"' (BAKHTIN, 2013, p. 293). Uma alteridade que, logo, se revela como a estrutura da consciência humana.

Em Para uma filosofia do ato (1993), uma das suas primeiras escriturações, Bakhtin já nos direciona para os aspectos conceituais do dialogismo através do seu conceito de arquitetônica, quando nos oferece os princípios gerais e indispensáveis da sua antropologia filosófica ${ }^{9}$ (BAKHTIN, 2017a, p. 47). Segundo o filósofo russo:

[...] é essa arquitetônica concreta do mundo real do ato realizado que a filosofia moral tem de descrever, isto é, não o esquema abstrato mas o plano ou desenho concreto do mundo de uma ação ou ato unitário e único, os momentos básicos concretos de sua construção de sua mútua disposição. Esses momentos básicos são eu-para-mim, outro-para-mim e eu-para-o-outro (BAKHTIN, 1993, p. 71).

Como nos indica Bakhtin, trata-se da presença constitutiva, necessária e reguladora do outro na estrutura da consciência do sujeito. Ao se instaurar em seu diálogo crítico e polêmico com o Idealismo Alemão ${ }^{10}$ e com o neokantismo (BRAN-

9 De forma explícita, Bakhtin se refere à sua antropologia filosófica, por exemplo, em Fragmentos de 1970-1971 (2017a), obra à qual nos remeteremos logo mais.

10 Para um maior entendimento da participação crítica do Idealismo Alemão na filosofia do Círculo de Bakhtin, indicamos o artigo de Taciane Domingues, que se intitula $O$ Círculo de

VILLARTA-NEDER, M. A., DIAS, F. L. C. Crítica responsiva a diálogos polêmicos com 0 conceito de dialogismo de Bakhtin 
Linha D’Água (Online), São Paulo, v. 33, n. 3, p. 25-54, set.-dez. 2020

DIST, 2002), Bakhtin nos mostra a alteridade como o centro das convergências dos sentidos e dos valores de uma cultura na história, pelos quais se formam, de maneira dialógica, os lugares dos sujeitos na eventicidade histórica do mundo, responsabilizando-se um pelo outro graças a uma atitude de não-álibi. Indo além, a dinâmica da arquitetônica põe-se como o cerne de irradiação e de localização do ato e, logo, da consciência do sujeito instaurado na historicidade. Situa-se, aí, a dialética $^{11}$ do dialogismo, pela qual se consubstanciam e para qual convergem, para

Bakhtin e o Idealismo Alemão: relações entre pensamento e língua (2017).

11 A dialética do dialogismo - à qual nos referimos, de igual modo, como a dialética dialógica - difere-se da dialética da tradição filosófica em alguns aspectos fundamentais. Como nos orienta o Dicionário de Filosofia (2007, p. 269), de Nicola Abbagnano, "esse termo, que deriva de diálogo, não foi empregado, na história da filosofia, com significado unívoco, que possa ser determinado e esclarecido de uma vez por todas; recebeu significados diferentes, com diversas inter-relações, não sendo redutíveis uns aos outros ou a um significado comum". Em Hegel (2003), a dialética, por exemplo, consiste no desenvolvimento e na forma, de modo mais geral, do movimento objetivo do Espírito, que se encontra instanciado e refletido na organização da história e da natureza, de modo independente e necessário. Revela-se como o desenvolvimento da própria realidade objetiva diante da razão - em Hegel, o real define-se como o racional. Trata-se de uma dialética de circularidade: o Espírito, absoluto e infinito, define-se como um ser-em-si, que se faz ser-para-fora-de-si para, em seguida, tornar-se a si como um ser -em-si-para-si (REALE; ANTISERI, 2005, p. 103), ligando-se à compreensão à conscientização de si por si mesmo através da atividade especulativa da ciência do espírito. A alteridade, aqui, estabelece-se no âmago do próprio Espírito consigo mesmo, em sua diversificação em direção ao seu devir ascendente. Segundo Reale e Antiseri (2005, p. 102), "o espírito se autogera, gerando ao mesmo tempo sua própria determinação, e superando-a plenamente". Em Bakhtin (1993), a dialética não se mostra como dada na história ou na natureza - seja espiritual, seja material - por si mesma, mas localizada nas formas de organização histórica da condição humana, estruturando-se no dialogismo da alteridade constitutiva e reguladora do ser humano. A dialética bakhtiniana, sem abstrair da contradição e da oposição, forma-se na consideração da incorporação arquitetônica da diversidade e da variabilidade das formas de manifestação dos sujeitos envolvidos sem a eliminação da diferença (ou da refração) advinda da unicidade de cada um. Poderíamos, também, referir-nos à dialética dialógica como arquitetônica, na qual se fazem necessários os excedentes de conhecimento e de visão (BAKHTIN, 2011c) dos sujeitos sobre si e sobre outrem a partir da uniocorrência do lugar de cada um na eventicidade histórica do mundo. Não se trata, portanto, de uma junção justaposta e mecânica - da multiplicidade de uma mesma unidade, como em Hegel -, mas, sim, arquitetônica e ética, pela qual se transformam de modo recíproco (BAKTHIN, 2017a, p. 36), que se torna dependente do distanciamento - вненаходимость (vnenakhodímost) - constitutivo e necessário. Uma suposta síntese, aqui, torna-se aberta e inconclusa enquanto sentidos históricos das formas de interação social, sempre se retratando como refratada diante da manifestação da multiplicidade excedente das relações alteritárias à luz das condições ideológicas e materiais da sociedade na qual se situam os sujeitos: entre o eu-para-mim, o outro-para-mim e o eu-para-o-outro (BAKHTIN, 1993, p. 71)

VILLARTA-NEDER, M. A., DIAS, F. L. C. Crítica responsiva a diálogos polêmicos com 0 conceito de dialogismo de Bakhtin 
Linha D’Água (Online), São Paulo, v. 33, n. 3, p. 25-54, set.-dez. 2020

a constituição dos sujeitos e para a formação da cultura. Tem-se, dessa forma, o mundo da cultura e o mundo da vida (BAKHTIN, 1993, p. 20) no ato responsivo de cada ser humano, o qual se responsabiliza, novamente, pelo seu não-álibi na eventicidade histórica do mundo através da sua alteridade constitutiva.

Diferindo de determinadas acepções segundo as quais se admitem a constituição e a existência de um $e u$ autossuficiente - autárquico, portanto -, cuja dinâmica de consciência de si mesmo se sustenta sobre a sua independência do outro ${ }^{12}$, a alteridade, não obstante, constitui-se como o centro e a condição para a concepção de um sujeito sob as premissas do Círculo de Bakhtin. A própria consciência de si, aqui, manifesta-se como uma reverberação da alteridade pela qual se instaura um sujeito como uma presença na eventicidade histórica do mundo. Em Fragmentos de 1970-1971 (2017a), Bakhtin, mais uma vez, ao se remeter ao conceito de arquitetônica, dedica-se a nos oferecer outra referência à alteridade inerente segundo a sua antropologia filosófica. De acordo com palavras do filósofo russo:

mantêm-se a excedência e a refração. Também, como falam Bularka e Buzgalin (2005, p. 7), "[...] a dialética do diálogo, da polifonia e da criatividade colaborativa está ligada à criação e à cognição no domínio da liberdade" - liberdade circunscrita, aliás, pelas condições históricas das organizações sociais. Uma dialética, portanto, na qual não se abole o ativismo responsivo e responsável de cada um, cuja formação se dá, entretanto, apenas na interdependência arquitetônica da alteridade, o que deve se encontrar na compreensão de nosso leitor quando nos referimos a uma forma de dialética em Bakhtin.

12 Referimo-nos a uma concepção cartesiana de sujeito, cuja primeira certeza existencial dependeria do exercício da dúvida metódica, pela qual se levaria à indubitabilidade de si ao conscientizar-se por si próprio, da qual se deriva a descoberta do cogito de maneira autossuficiente e independente, o que se resume na célebre afirmação de Descartes: penso, logo existo (cogito, ergo sum). Ou seja, o eu se instaura como indubitável através da sua própria atividade racional. Um exemplo segundo as próprias palavras de Descartes: "de maneira que, depois de haver pensado nisto e analisado cuidadosamente todas as coisas, se faz necessário concluir e ter por inalterável que esta proposição, eu sou, eu existo, é obrigatoriamente verdadeira todas as vezes que a enuncio ou que a concebo em meu espírito" (DESCARTES, 1999, p. 258). Em outras passagens de seu Meditações, o filósofo francês nos mostra ainda mais a certeza categórica do eu como o primeiro a se descobrir por meio da dúvida. Não negamos, porém, a importante atividade filosófica de Descartes - jamais poderíamos pensar em fazê-lo. $O$ que procuramos contrariar, contudo, é a possibilidade concreta de que assim se dê a consciência do sujeito sobre si (a formação, segundo a nossa ótica bakhtiniana, do seu eu-para-mim). Como veremos, a autoconsciência só se revela como uma realidade na e pela relação alteritária entre o eu e o outro.

VILLARTA-NEDER, M. A., DIAS, F. L. C. Crítica responsiva a diálogos polêmicos com 0 conceito de dialogismo de Bakhtin 
[..] qual é a índole da concepção de mim mesmo, do meu eu em seu todo? Em que ele se distingue essencialmente da minha concepção do outro? A imagem do $e u$ ou o conceito, ou o vivenciamento, a sensação, etc. A espécie de ser dessa imagem. Qual é a composição dessa imagem (como a integram, por exemplo, as concepções sobre o meu corpo, a minha aparência, o meu passado, etc.). O que compreendo por eu quando falo e vivencio: "eu vivo", “eu morro", etc. (“eu sou”, "eu não existirei”, "eu não existi”). Eu-para-mim e eu-para-o-outro, o outro-para-mim. $\mathrm{O}$ que em mim é dado imediatamente e o que é dado apenas através do outro. O mínimo e o máximo - a autossensação primitiva e a complexa autoconsciência. Mas o máximo desenvolve aquilo que já está jacente no mínimo. $\mathrm{O}$ desenvolvimento histórico da autoconsciência. Ela está ligada ao desenvolvimento dos recursos semióticos de expressão (acima de tudo da língua) (BAKHTIN, 2017a, p. 42-43 - destaques do autor).

Própria de uma antropologia filosófica, a raiz da problemática ontológica sobre o que é o ser humano se encontra firmada em uma tradição ocidental, cujas primeiras marcas se localizam já na filosofia de Sócrates [469 a.C.-399 a.C.]. Desde então, estende-se às discussões e às reflexões de diferentes filósofos de distintos períodos históricos, eclodindo-se, de maneira central e particular, em Descartes [1596-1650] - quando se liga à problemática do conhecimento, novamente. A partir daí, firmou-se uma concepção autárquica de sujeito, que se prolonga à nossa contemporaneidade através de formas variadas.

$\mathrm{Na}$ concepção do Círculo de Bakhtin, a localização inquestionável da presença de um eu como a instauração de uma presença ontológica na eventicidade histórica torna-se dependente da presença de um outro. $\mathrm{Na}$ citação anterior de Bakhtin, o filósofo russo indica-nos já a sua acepção de dialogismo. Um sujeito não consegue perceber-se e representar-se como uma presencificação uniocorrente no mundo histórico sem o excedente de visão (BAKHTIN, 2011c, p. 21) do outro, já que se marca, em si, por um vazio original - como por uma falta ontológica do simesmo (ou, na terminologia bakhtiniana, do mim-mesmo do eu-para-mim). Como afirma Bakhtin (2011c, p. 28):

é necessário algum esforço para me imaginar a mim mesmo nitidamente em face, desligar-me por completo de minha autossensação interior; conseguindo 
Linha D’Água (Online), São Paulo, v. 33, n. 3, p. 25-54, set.-dez. 2020

isto, somos afetados em nossa imagem externa por algum vazio original, por algo imaginário e um estado de solidão um tanto terrível dessa imagem.

Trata-se, portanto, de uma condição segundo a qual:

não posso viver do meu próprio acabamento e do acabamento do acontecimento, nem agir; para viver preciso ser inacabado, aberto para mim - ao menos em todos os momentos essenciais -, preciso ainda me antepor axiologicamente a mim mesmo, não coincidir com a minha existência presente (BAKHTIN, 2011c, p. 11).

Pelo seu não-álibi, o eu se vê na impossibilidade de não se constituir pelo seu movimento através do outro. Para formar-se como um eu-para-mim, deve se instaurar, através de um outro, um eu-para-o-outro. O não-álibi do sujeito, portanto, direciona-se à problemática do seu vazio original, cujo fundamento de princípio se manifesta na sua carência ontológica enquanto se limita à forma mesma de seu ser no mundo. Trata-se de uma condição ou de uma condenação da qual não se pode furtar. Torna-se necessário, aí, o outro, cuja presença se mostra como um espelho no qual o eu deve, refratadamente, refletir-se como um eu-para-o-outro para a formação de seu eu-para-mim enquanto uma representação através dos sentidos e dos valores da cultura na qual se inserem, constituindo-se por um dialogismo no qual o eu se dá, em ativa alteridade, um acabamento provisório. Como nos fala Bakhtin (2019, p. 51), "não sou eu que olho o mundo de dentro com os meus próprios olhos, mas sou eu que olho a mim mesmo com os olhos do mundo, com os olhos alheios; eu sou possuído por um outro".

Dessa maneira, para tornar-se um eu-para-mim, deve se tornar, em anterioridade dialética ${ }^{13}$, um eu-para-o-outro, única condição de possibilidade para a formação da sua consciência, pois apenas o outro torna-se a comparência pela qual se institui o eu como, em sua contingencialidade e em sua facticidade, uma presença na eventicidade histórica do mundo, o que se dá através dos sentidos e dos valores da cultura da organização histórica da sociedade na qual se encontram. De modo semelhante, o outro trata-se do meio pelo qual se formam (no sentido de aquisição

13 Lembremo-nos, de uma dialética dialógica.

VILLARTA-NEDER, M. A., DIAS, F. L. C. Crítica responsiva a diálogos polêmicos com 0 conceito de dialogismo de Bakhtin 
de uma forma) a corporatura e a vivência do eu, que se posiciona, portanto, como uma pertinência à mundanidade histórica por meio das suas alteridades ${ }^{14}$. Para a nossa compreensão, deve ser evidenciado o inacabamento ou a incompletude do sujeito, que não se permite identificar consigo próprio em absoluto, devido a sua própria condição humana. $\mathrm{O}$ seu acabamento se torna sempre provisório. Ao sujeito, não se aplica, portanto, o princípio lógico de identidade $\mathrm{A}=\mathrm{A}(\mathrm{ou} \mathrm{Eu}=\mathrm{Eu}$ ), uma vez que se manifesta como um devir pela alteridade.

Fora da exigência da alteridade, "o que em mim é dado imediatamente" (BAKHTIN, 2017a, p. 43)? Apenas o mínimo, segundo Bakhtin: "a autossensação primitiva” (BAKHTIN, 2017a, p. 43). O máximo, a autoconsciência, a concepção de si enquanto uma presença na eventicidade histórica do mundo, torna-se uma consequência da alteridade. Não há o eu sem o outro. Ao contrário, trata-se de posições de constituições dialógicas, sem que coincidam no espaço e no tempo, que se refratam no perpetuum mobile das suas arquitetônicas. Pautando-se sobre a alteridade absoluta, Bakhtin (2017a, p. 43) afirma-nos que "o eu se esconde no outro e nos outros, que ser apenas outro para os outros, entrar até o fim no mundo dos outros como outro, livrar-se do fardo de eu único (eu-para-mim) no mundo". Daí, o dialogismo manifestar-se como, sobretudo, uma compreensão da própria condição humana.

Do dialogismo arquitetônico ao composicional, as obras dostoievskianas se tornam, para Bakhtin, o indispensável exemplo mais bem acabado, o que se afirma nas seguintes palavras do filósofo russo: "a autoconsciência do herói em Dostoiévski é totalmente dialogada: em todos os seus momentos está voltada para fora, dirige-se intensamente a si, a um outro, a um terceiro. Fora desse apelo vivo para si mesma e para outros ela não existe nem para si mesma” (BAKHTIN, 2013, p. 292). No mundo romanesco de Dostoiévski, as definições gerais, portanto, da antropologia filosófica de Bakhtin se encontram representadas. Bakhtin, em Reformulação do livro sobre Dostoiérski (2011d), mostra-nos como a condição humana da consciência define-se na fronteira entre o eu e o outro (BAKHTIN, 2011d, p. 341). E, ainda:

14 E, aqui, parece-nos preciso uma compreensão extensiva do outro como um sujeito, uma cultura, um povo etc. Em resumo, uma presença com a qual se estabelece uma alteridade, sem a qual não se constitui um eu.

VILLARTA-NEDER, M. A., DIAS, F. L. C. Crítica responsiva a diálogos polêmicos com 0 conceito de dialogismo de Bakhtin 
Linha D'Água (Online), São Paulo, v. 33, n. 3, p. 25-54, set.-dez. 2020

eu tomo consciência de mim e me torno eu mesmo unicamente me revelando para o outro, através do outro e com o auxílio do outro. Os atos mais importantes, que constituem a autoconsciência, são determinados pela relação com outra consciência (com tu). A separação, o desligamento, o ensimesmamento como causa central da perda de si mesmo (BAKHTIN, 2011d, p. 341).

Trata-se de uma afirmação que se converge, de certo modo, para as considerações de Volóchinov sobre a relação constitutiva, dependente e reguladora entre a consciência humana e o signo ideológico. Em Marxismo e filosofia da linguagem (2018), Volóchinov nos direciona, por sua vez, para a absoluta dialogicidade histórica da consciência do sujeito por meio do seu conceito de signo ideológico (já que se trata de uma produção das interações sociais): na consciência do sujeito, ecoam as vozes ideológicas de outros por meio dos índices axiológicos dos horizontes valorativos de cada classe social (VOLÓCHINOV, 2018, p. 238). Inclusive, a vivência interior $^{15}$ de cada um define-se como um movimento contínuo à orientação social do sujeito ao se encarnar em signos ideológicos (VOLÓCHINOV, 2018, p. 207). A vivência, nesse sentido, "[...] é tão social quanto a estrutura da sua objetivação exterior” (VOLÓCHINOV, 2018, p. 207).

Como nos afirma o autor, "a consciência é um fato social e ideológico" (VOLÓCHINOV, 2018, p. 97), que se forma a partir de signos ideológicos no interior dos quais se refletem e se refratam as diferentes formas de configuração da arena de lutas de classes (VOLÓCHINOV, 2018, p. 113). A consciência, portanto, afirma-se como uma ordem compósita de diversos outros através da materialidade do signo ideológico, circunscrevendo-se pelo horizonte valorativo e orientando-se para o auditório social (VOLÓCHINOV, 2018, p. 205) da sociedade na qual se situa, em alteridade conflituosa e tensa, o que se alinha com a seguinte assertiva de

15 Conceito filosófico, que se encontra, também, no cerne conceitual da Fenomenologia de Edmund Husserl [1859-1938]. Em alemão, Erlebnis. Segundo o Dicionário de filosofia (2007, p. 1006) de Nicola Abbagnano, define-se como, de maneira geral, "[...] toda atitude ou expressão da consciência". Em Husserl (2006), afirma-se "[...] como um fato de consciência, logo, como um entre os demais conteúdos do cogito" (ABBAGNANO, 2007, p. 1006). Enquanto um fato de consciência, realiza-se como a experiência interior em fluxo contínuo (HUSSERL, 2006). Em Volóchinov (2018), a vivência não se forma para aquém da materialidade dos signos ideológicos advindos das comunicações discursivas e das interações sociais, determinando-se como um movimento ininterrupto à exterioridade através da alteridade na linguagem.

VILLARTA-NEDER, M. A., DIAS, F. L. C. Crítica responsiva a diálogos polêmicos com 0 conceito de dialogismo de Bakhtin 
Linha D’Água (Online), São Paulo, v. 33, n. 3, p. 25-54, set.-dez. 2020

Bakhtin (2011d, p. 341, grifo nosso): "todo o interior não se basta a si mesmo, está voltado para fora, dialogado, cada vivência interior está na fronteira, encontra-se com outra, e nesse encontro tenso está toda a sua essência".

Mais uma vez, o dialogismo reverbera no interior da própria estrutura da consciência, determinando-se como o indicativo inalienável da condição humana.

Em vista de nossos sucintos apontamentos epistemológicos sobre o conceito de dialogismo, voltemo-nos às nossas análises responsivas, nas quais se revelarão os pontos centrais de nossas discussões teóricas.

\section{Análise}

Uma das características da maneira como o percurso da argumentação e da discussão dos conceitos bakhtinianos de Emerson se constrói dá-se através de uma série minuciosa de escolhas e de organizações de posições críticas a certos pontos do pensamento de Bakhtin, utilizando-se, principalmente, de autores e críticos russos. $\mathrm{O}$ esforço da autora estadunidense parece indicar - contrapondo uma representação da recepção consagradora e celebratória de Bakhtin no exterior - a formação, dentro da União Soviética, de uma oposição por parte da crítica russa, o que poderia se configurar como um alerta para as leituras mais entusiastas e menos criteriosas do autor a partir de cujo nome se denomina o círculo de intelectuais em questão.

A nossa discussão se inicia, conforme nossos objetivos propostos, em direção a uma ponderação a partir de uma formulação do próprio Bakhtin. Estranha-nos o argumento de autoridade sobremodo presente na série de escolhas e de organizações de Emerson, quase como uma espécie de solipsismo cultural de caráter autocêntrico.

Assim, torna-se fundamental, por um lado, que atentemos para as condições de produção, de circulação e de recepção dos conceitos bakhtinianos em sua cultura, em sua língua e em seu tempo, enquanto um lócus singular somente a partir do qual se tornou possível a produção das suas reflexões enunciadas. Por um outro lado, faz-se necessário, no entanto, que nos atenhamos ao entendimento da incontornável distância - вненаходимость (vnenakhodímost) - do lugar uniocorrente a partir do qual se constituiu e enunciou o filósofo russo, uma exigência imprescindível para 
a formação contínua do ver-se de fora, de um lugar outro, de presença única, capaz de uma atribuição (ainda que temporária e provisória) de acabamento ou de inteireza - nолнота (polnota). Na relação com o representado lugar único de Bakhtin, forma-se a nossa condição dialógica de uma discussão fundamentada e ética pela qual se instaura a nossa responsividade responsável.

Vale-nos citar, então, as palavras de Bakhtin, quando da escrituração de um pequeno texto responsivo à revista Novi Mir:

[...] a grande causa para a compreensão é a distância do indivíduo que compreende - no tempo, no espaço, na cultura - em relação àquilo que ele pretende compreender de forma criativa. Isso porque o próprio homem não consegue perceber de verdade e assimilar integralmente nem sua própria imagem externa, nenhum espelho ou foto o ajudarão; sua autêntica imagem externa pode ser vista e entendida apenas por outras pessoas, graças à distância espacial e ao fato de serem outras (BAKHTIN, 2011e, p. 366, grifos do autor).

A leitura de conceitos, como os que se abrigam em uma concepção axiológica em linha semelhante a de Bakhtin, merece, antes de tudo, contemplar-se pela pergunta quanto à sua própria validade, cuja ausência de uma resposta (a inextricável relação de dialética dialógica entre essa constituição necessariamente intersubjetiva, única e concreta) torna-se uma abertura graças a qual o empreendimento crítico se esvazia ou se apequena. Isso pode, assim, despertar, no leitor atento, interpretações desconfiadas (o subtítulo de uma das partes de capítulo de Emerson sobre a crítica das noções de polifonia e dialogismo).

Um texto de efetivo caráter aporético pode se configurar como uma grande contribuição crítica, qualquer que seja a sua época ou o seu contexto. Uma aporte, aliás, para a persistente continuidade de uma instigação sobre certo fenômeno, tornando-se o meio pelo qual se perpetua, no leitor reflexivo sobre a matéria da discussão, o esforço diligente e ético de quem ouve as muitas vozes pelas quais se compõe um diálogo conflituoso e/ou polêmico. De nosso ponto de vista analítico, se o propósito do escrito de Emerson se configurava em direção semelhante, o empreendimento, em muitos aspectos, não se deu como tão bem-sucedido. 
Linha D’Água (Online), São Paulo, v. 33, n. 3, p. 25-54, set.-dez. 2020

Para uma adequada ilustração da linha de argumentação do texto de Emerson, vamos, em seguida, trazer parte das vozes pelas quais se compõe a crítica da autora estadunidense. Dentre as várias, destaca-se a do poeta e crítico estadunidense Aaron Fogel. Segundo Emerson:

[...] a tese de Fogel é a de que o diálogo, tal como invocado por Bakhtin, não é absolutamente a relação humana normal. O discurso humano, diz ele, é quase sempre forçado e restringido, ainda que o diálogo seja por vezes, quando efetivamente acontece, uma benção e um alívio, a tarefa de fazer com que aconteça entre duas pessoas é difícil e perigosa, sobretudo quando tentamos (e eis a parte não bakhtiniana), contra todas as expectativas e contra os interesses dos participantes, 'colocar tudo para fora'. [....] Independentemente de como Bakhtin embrulhe a questão, afirma Fogel, claro está que, na maior parte do tempo e para grande número de problemas humanos, o diálogo não é uma 'cura por meio da fala' (EMERSON, 2003, p. 169, grifo nosso).

Trata-se de um ponto no qual nos aparece, segundo as nossas análises interpretativas da base epistemológica do Círculo de Bakhtin, uma série de equívocos na compreensão de Fogel, endossada por Emerson, do conceito de diálogo - e, consequentemente, de dialogismo - de Bakhtin. De “[...] o diálogo, tal como invocado por Bakhtin, não é absolutamente a relação humana normal" (EMERSON, 2003, p. 169), deriva o nosso entendimento segundo o qual nos parece, sub-repticiamente, não se dar, com uma crítica precisão, uma distinção e uma delimitação dos níveis de definição epistêmica da proposta conceitual de diálogo delineados por Bakhtin, aos quais já nos remetemos: o arquitetônico e o composicional. $\mathrm{Na}$ compreensão de Fogel, dá-se uma ausência de diferenciação inerente às circunscrições da organização conceitual e lógica do campo epistemológico do Círculo de Bakhtin ${ }^{16}$, cujas consequências se desdobram.

16 Um campo epistemológico trata-se de um conjunto no interior do qual se interdependem e se ordenam, de forma completiva, dialética - no sentido, aqui, de uma interdependência recíproca para a formação de uma consubstanciação sintética - e responsiva, as categorias e os conceitos de uma certa teoria. Forma-se como uma organização epistêmica, também, através da distribuição de dispositivos metodológicos e de parâmetros lógicos. Trata-se, sobretudo, de uma estrutura recíproca, na qual se arranjam e se sistematizam os conceitos por meio de parâmetros. No campo epistemológico do Círculo de Bakhtin, por exemplo, correlacionam-se as categorias e os

VILLARTA-NEDER, M. A., DIAS, F. L. C. Crítica responsiva a diálogos polêmicos com 0 conceito de dialogismo de Bakhtin 
Conforme a afirmação de Fogel, o dialogismo se manifesta apenas, em primeiro plano, enquanto uma forma, de certa maneira e em determinado grau, da construção composicional de um enunciado - como se não se tratasse, ainda, de um reflexo da condição dialógica da existência dos próprios sujeitos na composicionalidade de sua enunciação. Parece-nos se referir, portanto, a um esquecimento ou a um silenciamento de duas importantes obras para os estudos do Círculo de Bakhtin: a primeira, Para uma filosofia do ato (1993), de Bakhtin, e, a segunda, Marxismo e filosofia da linguagem ${ }^{17}$ (2018), de Volóchinov, às quais já mencionamos. Fogel não se atenta, nesse sentido, para o caráter do entendimento metafórico do conceito de dialogismo do Círculo de Bakhtin como a alteridade constitutiva e reguladora, que se estende da constituição arquitetônica do sujeito à organização composicional do enunciado.

Como nos referimos na seção Referencial teórico de nosso trabalho, o dialogismo (no qual se enquadram a dialogicidade e o diálogo), primordialmente, refere-se à forma de constituição e de revelação da condição humana, segundo as colocações mais prementes de Para uma filosofia do ato (1993). O sujeito marca-se como dialógico desde a sua gênese histórica e social. O dialogismo, em uma chave bakhtiniana, evidencia-se já na ontologicidade do sujeito. E o diálogo, sobretudo, trata-se de um conflito (BAKHTIN, 2017a, p. 38). Nem se pode, de maneira contrapontística, invocar a possibilidade de existência do monólogo enquanto uma negação do diálogo. Como Bakhtin já afirma em Problemi dell’opera di Dostoersskij ${ }^{18}$ (2014), de 1929: "uma sólida voz monológica pressupõe uma sólida base social, pressupõe um 'nós', tanto faz se alguém toma ou não consciência disso" (BACHTIN, 2014, p. 142, destaque do autor, Trad. nossa $\left.{ }^{19}\right)$. A dimensão dialética da dialogicidade

conceitos de diálogo, de enunciado e de polifonia, cujas posições se constituem e se demarcam, de maneira contínua e movente, através da sua localização e da sua organização no interior do quadro da teoria bakhtiniana, modificando-se, no entanto, ao se submeterem - no respeito aos seus limites - a uma aplicação, a uma revisão, a uma ampliação e a uma crítica.

17 Cuja primeira edição é de 1929.

18 Problemas da obra de Dostoiévski, à qual nos referimos, a partir da edição russa, como Problemas da criação de Dostoiévski.

19 Em italiano: "una salda voce monologica presuppone una salda base sociale, presupone un 'noi', non importa se in maniera consapevole o meno" (BACHTIN, 2014, p. 142, destaque do autor).

VILLARTA-NEDER, M. A., DIAS, F. L. C. Crítica responsiva a diálogos polêmicos com 0 conceito de dialogismo de Bakhtin 
Linha D’Água (Online), São Paulo, v. 33, n. 3, p. 25-54, set.-dez. 2020

discutida por Bakhtin - diante de uma leitura atenta - eclode fortemente na visão expressa pelo trecho acima. De outra maneira, o sujeito, mesmo no monólogo, fundamenta-se em e encaminha-se para um diálogo, sempre à luz de uma alteridade tensa. A negação da nossa condição dialógica torna-se a eliminação da nossa inserção nas organizações espaciais e nas configurações temporais do mundo histórico sob o imperativo da convivência/acontecimento - coбbımue (sobýtie) - com o outro.

Localizando-se ainda em seu equívoco, Fogel, ao dizer que o discurso humano é "[...] forçado e restringido [...]" (EMERSON, 2003, p. 169), esquece-se de que qualquer atitude de consciência se condiciona e se enquadra por um auditório social. Como nos aponta Volóchinov (2018, p. 205, grifos do autor), "o mundo interior e o pensamento de todo indivíduo possuem seu auditório social estável, e nesse ambiente se formam os seus argumentos interiores, motivos interiores, avaliações etc.”. Qualquer discurso - rememoremos: a consciência trata-se de um discurso interior pela constituição sígnica do psiquismo humano (VOLÓCHINOV, 2018, p. 100) -, desde a sua estrutura, determina-se, portanto, pela sua orientação ao outro, seja ausente, seja presente. A palavra e/ou o discurso - слово (slovo) - trata-se de "[...] um ato bilateral. Ela é determinada tanto por aquele de quem ela procede quanto por aquele para quem se dirige" (VOLÓCHINOV, 2018, p. 205, grifos do autor). Logo, Fogel se encontra, segundo os preceitos analíticos de Volóchinov (2018), definindo-se como um subjetivista individualista, não se importando com a dialogicidade ideológica da consciência. De semelhante modo, não se atenta sequer para a responsividade constante dos sentidos - a compreensão como um enunciado responsivo (VOLÓCHINOV, 2018, p. 232). Deriva, daí, o seu tratamento monológico da linguagem e do sujeito.

A partir de "[...] colocar tudo para fora [...]" (EMERSON, 2003, p. 169), revisitamos uma concepção de diálogo, de tradição ocidental, a partir da qual nos parece se desenvolver a compreensão equivocada de Fogel do conceito bakhtiniano: a do diálogo socrático, que se funda em seu método dialógico de pergunta e resposta (REALE; ANTISERI, 2003, p. 91-93), nomeando-se como, também, maiêutica segundo o diálogo Teeteto de Platão [428/427-348/347] (PLATÃO, 2013, p. 105). Trata-se de uma obra na qual se instaura um diálogo entre Sócrates, Teodoro de 
Linha D’Água (Online), São Paulo, v. 33, n. 3, p. 25-54, set.-dez. 2020

Cirene e Teeteto sobre a natureza do conbecimento. Sócrates, lá, refere-se à sua arte do seguinte modo:

\begin{abstract}
Sócrates - A minha arte obstétrica tem atribuições iguais às das parteiras, com a diferença de eu não partejar mulher, porém homens, e de acompanhar as almas, não os corpos, em seu trabalho de parto. Porém a grande superioridade da minha arte consiste na faculdade de conhecer de pronto se o que a alma dos jovens está na iminência de conceber é alguma quimera e falsidade ou fruto legítimo e verdadeiro (PLATÃO, 2013, p. 69).
\end{abstract}

"Partejar", "dar à luz" e "parir" o conhecimento: a essência do homem, o que se forma e se encontra no seu interior. Sócrates se apresenta, assim, como o parteiro das almas. No plano formal e organizacional, o método dialógico de Sócrates funda-se na articulação entre dois momentos: o irônico-refutatório e o maiêutico (REALE; ANTISERI, 2003, p. 92). No primeiro, põe-se a interrogar e a refutar, de modo irônico, o seu interlocutor. No segundo, dedica-se a, após a eliminação dos erros do seu outro, partejar o conhecimento do seu interlocutor. Segundo Reale e Antiseri (2003), Sócrates:

[...] seguia com seus interlocutores um método de pergunta-resposta, apresentando-se como aquele que não sabe e pede para ser instruído, e - pelo fato de efetivamente afirmar que todo homem, em relação a Deus, e não - sapiente -, muito frequentemente esta atitude era uma simulação irônica, para constranger o adversário a expor completamente suas teses (REALE; ANTISERI, 2003, p. 92).

A maiêutica, epistemologicamente, limita-se ao campo conceitual e metodológico da filosofia socrática, que se apresenta através das escriturações de Platão. Liga-se ao, de modo estrito e necessário, seu conceito de alma - a essência humana -, cuja definição se identifica com a consciência. Questionando-se sobre a natureza do homem, Sócrates leva-se à conclusão, nas palavras de Reale e Antiseri (2003, p. 95), segundo a qual "o homem é a sua alma [...]". Ainda conforme os mesmos autores: “[...] por 'alma' Sócrates entende a nossa razão e a sede de nossa atividade pensante e eticamente operante. Em poucas palavras: para Sócrates a alma é o eu 
Linha D’Água (Online), São Paulo, v. 33, n. 3, p. 25-54, set.-dez. 2020

consciente, ou seja, a consciência e a personalidade intelectual e moral" (REALE; ANTISERI, 2003, p. 95).

O cuidado da alma deriva-se a partir de uma atitude de virtude, meio pelo qual tem-se a sua natureza: boa e perfeita (REALE; ANTISERI, 2003, p. 95). Como? Através do conhecimento, que se forma, por sua vez, no interior do sujeito, em relação ao qual se coloca Sócrates apenas como um meio para que consiga concebê-lo de modo inequívoco: "o que é fora de dúvida é que nunca aprenderam nada comigo; neles mesmos é que descobrem as coisas belas que põem no mundo, servindo, nisso tudo, eu e a divindade como parteira" (PLATÃO, 2013, p. 69-70).

Em primeiro lugar, a concepção socrática - segundo uma possível leitura da citação de Platão ${ }^{20}$-, que reverbera nas considerações de Fogel, parece-nos se delinear como uma das raízes ancestrais e genéticas de uma forma do subjetivismo individualista, que se tradicionalizou em nosso ocidente: "o psiquismo individual" (VOLÓCHINOV, 2018, p. 148) torna-se a fonte primária e autônoma da linguagem, do discurso e do conhecimento, que não se formam, em um primeiro momento, nas relações de interlocução entre um eu e um outro. Ao contrário, criam-se na alma humana, externalizando-se através de uma forma dialogal. Pode se derivar, daí, uma concepção autárquica de sujeito: o eu forma-se sem o outro para, depois, já cada qual pronto em e por si mesmo, se encontrarem.

Em segundo lugar, configura-se como, se observarmos o método maiêutico em uma série de diálogos platônicos, uma composição de alta dialogia desde a estrutura formativa do conhecimento, cuja expressão consistiria - se olharmos criticamente para ela - em uma derivação e em uma extensão de uma opinião preconcebida na alma humana. O conhecimento final, portanto, seria instituído como uma produção suposta do processo de interação dialógica entre os sujeitos envolvidos, cujo núcleo irradiador, contudo, situa-se na essência do interlocutor de Sócrates, que se instaura, por sua vez, como o meio pelo qual se realiza a cura da alma "[...] por meio da fala [...]" (EMERSON, 2003, p. 169). Como educador, Sócrates dedicava-se a ser o canal por intermédio do qual emergiam as virtudes

20 Tradição perpetuada, em aspecto semelhante, na filosofia aristotélica e estoica.

VILLARTA-NEDER, M. A., DIAS, F. L. C. Crítica responsiva a diálogos polêmicos com 0 conceito de dialogismo de Bakhtin 
Linha D’Água (Online), São Paulo, v. 33, n. 3, p. 25-54, set.-dez. 2020

sem as quais não se desenvolveria a natureza boa e perfeita - logo, curada dos seus vícios - da alma dos seus interpelados.

Trata-se do ponto a partir do qual se orienta Bakhtin, à luz de uma perspectiva da forma e do gênero, para o diálogo socrático em Problemas da poética de Dostoiéruski (2013), identificando-o como um dos antecessores, na antiguidade clássica, da forma dialógica e polifônica dos romances de Dostoiévski. O que nos parece escapar a Fogel e, consequentemente, a Emerson, encontra-se no fato de que a menção de Bakhtin ao diálogo socrático como uma antecedência histórica à forma romanesca do autor russo não implica que a concepção bakhtiniana se assente na mesma premissa.

A tese de Fogel, logo, acaba sendo endossada pela argumentação de Emerson. Muito embora a autora estadunidense tenha lido Fragmentos de 1970-1971, não se propõe a refutá-la. E, em Fragmentos de 1970-1971 (2017a), manifesta-se, de modo claro e direto, a concepção de diálogo de Bakhtin: conflito e tensão (BAKHTIN, 2017a, p. 38), muito em convergência com a maneira como se delineia a compreensão de Volóchinov sobre o embate ideológico no interior do signo (VOLÓCHINOV, 2018, 113). Diz-nos Bakhtin: "para cada indivíduo, todas as palavras se dividem nas suas próprias palavras e nas do outro, mas as fronteiras entre elas podem confundir-se, e nessas fronteiras desenvolve-se uma tensa luta dialógica" (BAKHTIN, 2017a, p. 38, grifos nossos). E, indo além, continua:

[...] eu vivo em um mundo de palavras do outro. E toda a minha vida é uma orientação nesse mundo; é reação às palavras do outro (uma reação infinitamente diversificada), a começar pela assimilação delas (no processo de domínio inicial do discurso) e terminando na assimilação das riquezas da cultura humana (expressa em palavras ou em outros materiais semióticos). A palavra do outro coloca diante do indivíduo a tarefa especial de compreendê-las (essa tarefa não existe em relação em minha própria palavra ou exige em seu sentido outro). Para cada indivíduo, essa desintegração de todo o expresso na palavra em um pequeno mundinho das suas palavras (sentidas como suas) e o imenso e infinito mundo das palavras do outro são o fato primário da consciência humana e da vida humana [...] (BAKHTIN, 2017a, p. 38, grifos nossos).

VILLARTA-NEDER, M. A., DIAS, F. L. C. Crítica responsiva a diálogos polêmicos com 0 conceito de dialogismo de Bakhtin 
Conflito, tensão, embate e luta: eis as formas da concepção bakhtiniana de diálogo, cujos pontos nucleares se refletem, aliás, no entendimento de Bakhtin sobre a formação da polêmica (BAKHTIN, 2013, p. 224). Na constituição dos sujeitos (na necessária dependência do eu do outro, que se formam no seu encontro, um no e pelo outro), na formação da responsividade retrospectiva e prospectiva (mesmo tratando-se de um monólogo, dá-se a compreensão responsiva e a resposta dialógica) e na composição intrínseca dos enunciados. O dialogismo da ordem composicional determina-se pelo dialogismo da ordem arquitetônica.

E é a concepção de diálogo e de dialogismo enquanto tensão absoluta de ativismos responsivos que se manifesta, segundo Bakhtin (2013), em Dostoiévski: os romances dostoievskianos configuram-se como vórtices polifônicos de conflitos, de embates e de lutas entre sujeitos históricos, reverberando-se no interior das consciências uniocorrentes de cada um, que se manifestam e se formam na e pela linguagem:

[...] compreende-se perfeitamente que no centro do mundo artístico de Dostoiévski deve estar situado o diálogo, e o diálogo não como meio, mas como fim. Aqui o diálogo não é limiar da ação, mas a própria ação. Tampouco é um meio de revelação, de descobrimento do caráter como já acabado do homem. Não, aqui, o homem não apenas se revela exteriormente como se torna, pela primeira vez, aquilo que é, não só para os outros, mas também para si mesmo. Ser significa comunicar-se pelo diálogo (BAKHTIN, 2013, p. 292-293, grifos nossos).

Por fim, Emerson endossa, igualmente, visões que demandam uma elucidação mais aguda. A autora se apoia em Gatchev para afirmar que Bakhtin teria destruído

[...] a dimensão vertical; tudo era sublimado e nivelado segundo um eixo "EuTu", amoroso e horizontal, em que a possibilidade sempre presente da comunicação benevolente entre iguais suplantava - ou, pelo menos, mantinha sob controle - aquelas ansiedades que anos depois iriam definir as paisagens mais áridas do existencialismo ocidental. (EMERSON, 2003, p. 21)

A reiteração de críticas e a comparação de perspectivas - aqui, no caso, com o Existencialismo - interessam-nos sobremodo, pois se fundamenta, parece-nos, sobre 
Linha D’Água (Online), São Paulo, v. 33, n. 3, p. 25-54, set.-dez. 2020

a ignorância do conceito de terceiro. Ignora, igualmente, a própria noção de enunciado/enunciação - высказыьвание (vyskázyvanie). Trata-se de uma visão pendular e dicotômica: ou a suposta utopia alienante de algo visto como um "diálogo amoroso" em Bakhtin, ou um derrotismo fatalista de uma forma de Existencialismo. Em que aspecto ambos falhariam? Quais seriam os seus possíveis contrapontos?

Uma das perspectivas possíveis seria a de uma concepção essencialista, em cujo bojo se desenvolve a certeza da formação preconcebida da essência definidora e determinante da existência do ser humano. Um em si mesmo, dado e esférico, acabado e definido, para o qual não se pode reclamar a mutação, a diversificação, o desenvolvimento, o inacabamento, a incompletude, a abertura, a transformação e/ ou a variação - enfim, o devir. No âmago da essência - enquanto um em si como uma necessidade -, a contingência e a facticidade se abolem, aniquilando-se o não -álibi do ser humano enquanto um ser de responsabilidade ética por si e por outrem como definidores de si mesmos na eventicidade histórica do mundo. Trata-se do que é, ao qual se aplica à ideia lógica de identidade absoluta. A substância igual, finalizada e determinante. A existência seria determinada pela essência. Eis-nos no solo do essencialismo, ao qual a axiologia bakhtiniana se coloca contra, aliás. Não valeria a pena, logo, a insistência na constitutividade do diálogo, porque haveria, no ser humano, uma essência cuja formação prescindiria da palavra, da historicidade e, portanto, da alteridade. Ou uma palavra que abstrairia do outro para quem poderia se dirigir ou de quem poderia derivar. A negação do dialogismo, aqui, pode vincular-se à afirmação do essencialismo, com o sufocamento do vir-a-ser dos sujeitos através, unicamente, da alteridade ${ }^{21}$.

${ }^{21}$ O dialogismo não se filia ao Existencialismo - sob as suas mais variadas formas -, advirtamos. No entanto, pode colocar-se em um intersecção aceitável com certa corrente existencialista no inteior do espectro de negação do essencialismo ao se fundamentarem sobre uma concepção de ser humano como aberto, inconcluso e processual, cujas definições se tornam mutáveis graças às formas de alteridade às quais se submetem, sob a ordem da historicidade da condição humana. Um exemplo possível encontra-se no existencialismo ateu de Jean-Paul Sartre, para quem o ser humano se define, enquanto um Para-si (SARTRE, 2015), como um "vazio" de si mesmo, cuja forma de ser se dá como a de não-ser - ou seja, como uma negação perpétua do em si. Nas palavras de Sartre (2015, p. 128), "[...] o Para-si é. Pode-se dizer: é, mesmo que apenas a título de ser que não é o que é e é o que não é". Daí, deriva-se a célebre frase da filosofia de Sartre: "[...] a existência precede a essência [...]" (SARTRE, 2014, p. 18). Consequentemente, o ser humano se responsabiliza pela constituição de si e de outrem,

VILLARTA-NEDER, M. A., DIAS, F. L. C. Crítica responsiva a diálogos polêmicos com 0 conceito de dialogismo de Bakhtin 
Linha D’Água (Online), São Paulo, v. 33, n. 3, p. 25-54, set.-dez. 2020

Uma outra perspectiva possível, que se destaca pela discussão de dois autores russos, encontra-se esclarecida no texto Os próximos cem anos de Mikhail Bakhtin: a dialética do diálogo versus a metafísica do pós-modernismo (2005), de Bulavka e Buzgalin, que se constitui como uma resposta de contraponto crítico ao texto de Emerson. Trata-se de, segundo os autores, uma visão do pós-modernismo. Para ambos os autores russos:

[...] se Bakhtin fala de uma transformação dialética da cultura em história, o pósmodernista tenta a qualquer custo permanecer dentro da cultura. Enfatizamos: a qualquer custo, mesmo chegando a consumi-la. O pós-modernismo é, portanto, como uma cobra que tenta engolir seu próprio rabo. Como comentou Bakhtin: "A tentativa de encontrar-se no produto de um ato de visão estética é uma tentativa de abandonar-se ao não-ser." Apenas quando a cultura se torna a base de construção da história e o indivíduo se torna sujeito é que a história é preenchida com um sentido cultural autêntico, enquanto a cultura se torna plena de um drama genuíno (BULAVKA; BUZGALIN, 2005, p. 14).

Em retorno a uma discussão a partir da qual se iniciou o nosso artigo, a relação do indivíduo com a cultura se dá na condição de sujeito, cuja constituição profunda se realiza apenas com, por e para outrem. O diálogo, para Bakhtin, é a condição dos acontecimentos únicos e concretos pelos quais se compõem as arquitetônicas dentro da qual (se) fazem (n)o mundo.

Desde o princípio, o que nos inquietou, com relação à tentativa de trajetória crítica e de organização aporética da argumentação de Emerson, esbarra na forma como a presença da voz da autora se faz patente no diálogo com o campo axiológico-epistemológico-teórico do Círculo de Bakhtin. A quais correntes do pensamento russo ela empresta a atenção e como articula as réplicas às e das noções bakhtinianas. Bakhtinianamente, não há álibi para cada sujeito, situado no tempo

\footnotetext{
à luz da alteridade. Orienta-nos o filósofo francês: "para obter qualquer verdade sobre mim é necessário que eu passe pelo outro. $O$ outro é indispensável para minha existência, tanto quanto, ademais, o é para o meu autoconhecimento. Nestas condições, a descoberta de meu íntimo revela-me, ao mesmo tempo, o outro como uma liberdade colocada diante de mim, que sempre pensa e quer a favor ou contra mim. Assim, descobrimos imediatamente um mundo que chamaremos de intersubjetividade, um mundo em que o homem decide o que ele é e o que os outros são" (SARTRE, 2014, p. 34).
}

VILLARTA-NEDER, M. A., DIAS, F. L. C. Crítica responsiva a diálogos polêmicos com 0 conceito de dialogismo de Bakhtin 
Linha D’Água (Online), São Paulo, v. 33, n. 3, p. 25-54, set.-dez. 2020

e no espaço, na cultura e na coexistência com seus outros (internos e externos). Seu diálogo amoroso, que é a consciência intersubjetiva das responsabilidades mútuas e inescapáveis, transforma-se e dissolve-se em leituras do mundo pós-soviético, nas responsabilidades, muitas vezes, que se liquefazem no individualismo solipsista, na celebração de um mercado invisível e leviatânico, cuja mão implacável tornaria impossível o diálogo, porque tornaria impossível que mesmo os mais solitários monólogos respondessem e suscitassem a história dos outros (com) que(m) fomos, seremos, (nos) encontraremos.

\section{Considerações finais}

Como objetivo de nosso artigo, elegeram-se a nossa análise e nossa discussão a partir de nossa leitura crítica, inquieta e responsiva do conceito de dialogismo feita por Caryl Emerson em seu livro Os 100 primeiros anos de Mikhail Bakbtin. Procuramos, a partir daí, fundar-nos na reflexão e na refração sobre o tenso diálogo de críticos com os enunciados do Círculo de Bakhtin.

Para fazê-lo, procuramos nos fundamentar sobre o correlacionamento não somente das posições majoritariamente de contraponto invocadas pela autora estadunidense, mas das implicações daí derivadas, frente a uma compreensão que se pretende dialética e dialógica do campo bakhtiniano, tal como este se propõe existir.

Em nosso percurso, identificamos, sob a aparência de uma aporia - interessante, criticamente, para a co-construção com o leitor, de uma perspectiva crítica, cujo acabamento fosse a constituição de um lugar analítico de caráter singular para cada um dos possíveis leitores -, uma predominância da invocação de vozes que se constituem por um ver-se de fora em uma distância ${ }^{22}$ - вненаходимость (vnenakhodimost) -, que se deixam de fazer as perguntas necessárias, sob certas orientações éticas em direção à lógica de organização do conhecimento, para o lugar do outro, objeto da crítica, de forma, substancialmente, profunda e atenta.

Se, para certos críticos trazidos para o texto pela argumentação de Emerson, Bakhtin deixa-se desconsiderar "[...] a distância prática que existe entre as

22 Tzvetan Todorov traduz essa palavra russa pelo neologismo exotopia.

VILLARTA-NEDER, M. A., DIAS, F. L. C. Crítica responsiva a diálogos polêmicos com 0 conceito de dialogismo de Bakhtin 
Linha D’Água (Online), São Paulo, v. 33, n. 3, p. 25-54, set.-dez. 2020

pessoas na vida real [...]" (EMERSON, 2003, p. 170) (como no caso de Linetsky) ou ser visto como quem postula uma noção de diálogo em $P C D$ que seria “[...] otimista, romântico-sentimental do diálogo recíproco [...]” (como no Bonestkaia) (EMERSON, 2003, p. 182), cabe-nos a contraposição da estranheza de quem, de um outro lugar concreto e único - mas em diálogo tenso e responsivo -, põe-se à cocriação de uma leitura diferente dos compromissos axiológicos e epistemológicos do Círculo de Bakhtin.

Trata-se de um lugar possível - nem de culto à personalidade, nem de niilismo alienante - que se funda desde outros leitores e críticos da produção bakhtiniana até o esforço de um estudo e de uma réplica de quem, como sujeitos expressivos e falantes nos conflitos exotópicos da alteridade, entendem-se na corrente da comunicação discursiva do diálogo - sempre tenso -, mas, de modo atento, responsável para com as provocações do pensamento bakhtiniano.

Nessa trajetória, cabe-nos, inclusive, a reflexão ética e teórica sobre os sentidos da insistência de Bakhtin em uma leitura da obra de Dostoiévski com outras chaves em uma sociedade soviética para a qual, à época do filósofo russo, ambos não se colocavam como os mais representativos do cânone literário, teórico e/ou político. A concordância ou não com conclusões às quais se fez chegar o filósofo russo importa-nos pouco. Como já nos referimos antes, Bakhtin, já no final de $P C D$ - texto mantido em PPD -, aponta-nos para, mesmo na solidez da voz monológica, a inextrincável presença constitutiva e reguladora de um nós pressuposto. Antes de mais nada, "ser significa conviver" (BAKHTIN, 2011d, p. 341). Esperamos, certamente, poder contribuir para que o olhar da dialética dialógica possa se constituir como uma distância crítica e necessária aos sujeitos que se pretendem ver e compreender, em uma formação ininterrupta, no diálogo tenso, mas responsável de/por si e de/por outrem.

\section{Referências}

ABBAGNANO, N. Dicionário de filosofia. 5. ed. São Paulo/SP: Martins Fontes, 2007. 
Linha D’Água (Online), São Paulo, v. 33, n. 3, p. 25-54, set.-dez. 2020

BACHTIN,M.M.Problemi della opera de Dostoievskij/Проблемы Творчества Достоевского. In: PONZIO, A. (Org.) Michail Bachtin e il suo Circolo. Opere 1919-1930. Traduzione per Augusto Ponzio e Luciano Ponzio. Testo russo a fronte. Milano: Bompiani, 2014.

BAKHTIN, M. Para uma filosofia do Ato. Trad. exclusiva para uso didático e acadêmico de Carlos Alberto Faraco e Cristóvão Tezza de Toward a Philosophy of the Act. Austin: University of Texas Press, 1993.

BAKHTIN, M. Apontamentos de 1970-1971. In: BAKHTIN, M. Estética da criação verbal. 6. ed. Trad. de Paulo Bezerra. São Paulo/SP: Editora WMF Martins Fontes, 2011a, p. 367-392.

BAKHTIN, M. Arte e responsabilidade. In: BAKHTIN, M. Estética da criação verbal.6. ed. Trad. de Paulo Bezerra. São Paulo/SP: Editora WMF Martins Fontes, 2011b, p. XXXIII-XXXIV.

BAKHTIN, M. O autor e o personagem na atividade estética. In: BAKHTIN, M. Estética da criação verbal. 6. ed. Trad. de Paulo Bezerra. São Paulo/SP: Editora WMF Martins Fontes, 2011c, p. 3-192.

BAKHTIN, M. Reformulação do livro sobre Dostoiévski. In: BAKHTIN, M. Estética da criação verbal. 6. ed. Trad. de Paulo Bezerra. São Paulo/SP: Editora WMF Martins Fontes, 2011d, p. 337-357.

BAKHTIN, M. Os estudos literários hoje. In: BAKHTIN, M. Estética da criação verbal. 6. ed. Trad. de Paulo Bezerra. São Paulo/SP: Editora WMF Martins Fontes, 2011e, p. 359-366.

BAKHTIN, M. Problemas da poética de Dostoiérski. Trad. do russo por Paulo Bezerra. 5. ed. Rio de Janeiro/RJ: Forense Universitária, 2013.

BAKHTIN, M. Os gêneros do discurso. Trad. do russo por Paulo Bezerra. São Paulo: Editora 34, 2016.

BAKHTIN, M. Fragmentos de 1970-1971. In: BAKHTIN, M. Notas sobre literatura, cultura e ciências humanas. Trad. do russo por Paulo Bezerra. São Paulo/SP: Editora 34, 2017a, p. 21-56.

BAKHTIN, M. Por uma metodologia das ciências humanas. In: BAKHTIN, M. Notas sobre literatura, cultura e ciências humanas. Trad. do russo por Paulo Bezerra. São Paulo/SP: Editora 34, 2017b, p. 57-79.

VILLARTA-NEDER, M. A., DIAS, F. L. C. Crítica responsiva a diálogos polêmicos com 0 conceito de dialogismo de Bakhtin 
Linha D’Água (Online), São Paulo, v. 33, n. 3, p. 25-54, set.-dez. 2020

BAKHTIN, M. O homem ao espelho: apontamentos dos anos 1940. Trad. do russo para o italiano por Augusto Ponzio. Trad. do Italiano por Marisol Barenco de Melo. São Carlos/SP: Pedro \& João Editores, 2019.

BRAIT, B.; MELO, R. Enunciado/enunciado concreto/enunciação. In: BRAIT, B. (Org.). Bakhtin: conceitos-chave. 5. ed. São Paulo/SP: Contexto, 2016, p. 61-78.

BRANDIST, C. The Bakbtin Circle: Philosophy, Culture and Politics. Lodres: Pluto, 2002.

BUBER, M. Do diálogo e do dialógico. Trad. de Marta Ekstein de Souza Queiroz e Regina Weinberg. São Paulo/SP: Perspectiva, 1982

BULAVKA, L; BUZGALIN, A. Os próximos cem anos de Mikhail Bakbtin: a dialética do diálogo versus a metafísica do pós-modernismo. Revista Novos Rumos, Ano 20, n. 44, 2005, p. 4-14. DOI: https://doi.org/10.36311/0102-5864.20.v0n44.2130. Acesso em 20 de maio de 2020.

DESCARTES, R. Meditações. In: DESCARTES, R. Descartes. Coleção Os Pensadores. Trad. de Enrico Corvisieri. São Paulo/SP: Nova Cultural, 1999, p. 233-334.

DOMINGUES, T. O Círculo de Bakhtin e o Idealismo Alemão: relações entre pensamento e língua. Estudos Linguísticos, São Paulo/SP, v. 46, n. 2, 2017, p. 641-654. DOI: http://dx.doi. org/10.21165/el.v46i2.1642. Acesso em 20 de maio de 2020.

EMERSON, C. Os cem primeiros anos de Mikhail Bakbtin. Trad. de Pedro Jorgensen JR. Rio de Janeiro/RJ: DIFEL, 2003.

GRILLO, S.; AMÉRICO, E. Glossário. In: VOLÓCHINOV, V. N. Marxismo e filosofia da linguagem: problemas fundamentais do método sociológico na ciência da linguagem. 2. ed. Trad. do russo por Sheila Grillo e Ekaterina Vólkova Américo. São Paulo/SP: Editora 34, 2018, p. 353-368.

HEGEL, F. Fenomenologia do Espírito. Trad. de Paulo Meneses. 2. ed. Petrópolis/RJ: Vozes, 2003.

HUSSERL, E. Ideias para uma fenomenologia pura e para uma filosofia fenomenológica: introdução geral à fenomenologia pura. Trad. de Márcio Suzuki. Aparecida/SP: Ideias \& Letras, 2006.

VILLARTA-NEDER, M. A., DIAS, F. L. C. Crítica responsiva a diálogos polêmicos com 0 conceito de dialogismo de Bakhtin 
Linha D’Água (Online), São Paulo, v. 33, n. 3, p. 25-54, set.-dez. 2020

JAKUBINSKIJ, L. Sobre a fala dialogal. Trad. de Dóris de Arruda C. da Cunha,;Suzana Leite Cortez. São Paulo/SP: Parábola, 2015.

PLATÃO. Obras Completas - volume 2: diálogos polêmicos. Centaur Editions, 2013. Livro digital.

REALE, G.; ANTISERI, D. História da filosofia, v. 1: filosofia pagã e antiga. Trad. de Ivo Storniolo. São Paulo/SP: Paulus, 2003, p. 91-105.

REALE, G.; ANTISERI, D. História da flosofia, v. 5: do romantismo ao empiriocriticismo. Trad. de Ivo Storniolo. São Paulo/SP: Paulus, 2005, p. 95-147.

SARTRE, J-P. O existencialismo é um humanismo. Trad. de João Batista Kreuch. 4. ed. Petrópolis/ RJ: Vozes, 2014.

SARTRE, J-P. O ser e o nada: Ensaio de ontologia fenomenológica. Trad. de Paulo Perdigão. 24. ed. Petrópolis/RJ: Vozes, 2015.

SOBRAL, A. A estética em Bakhtin (literatura, poética e estética). In: DE PAULA, L.; STAFUZZA, G. (Orgs.). Círculo de Bakbtin: teoria inclassificável. Série Bakhtin: Inclassificável, v. 1. Campinas/SP: Mercado de Letras, 2010, p. 53-88.

VOLÓCHINOV, V. Marxismo e filosofia da linguagem: problemas fundamentais do método sociológico na ciência da linguagem. 2. ed. Trad. do russo por Sheila Grillo e Ekaterina Vólkova Américo. São Paulo/SP: Editora 34, 2018.

Recebido: 20/06/2020.

Aprovado: 30/07/2020.

VILLARTA-NEDER, M. A., DIAS, F. L. C. Crítica responsiva a diálogos polêmicos com 0 conceito de dialogismo de Bakhtin 